\title{
Az internet demokratizáló hatása
}

\section{The Democratizing Effect of the Internet}

\section{Összefoglalás}

A cikk megpróbál érdemben megfelelni arra a kérdésre, hogy az információs sztráda lakossági igénybevételének terjedése vajon elvezet-e - rövid idôtávon - a demokrácia térhódításához. A cikk igazolja továbbá, hogy az információs sztráda egy eszköz, ami adott körülmények között erôsíti a demokratikus irányultságot, de éppúgy lehetôséget is biztosít a demokratikus intézményrendszer támadására és múködésének akadályozására.

Kulcsszavak: internet, demokrácia, iszlám országok, internethasználat

\section{Summary}

Answer is sought to the question whether the spread of the information highway in the population leads to democracy over the short term. It is evidenced that the information highway is a means that does indeed improve democratic approach among certain conditions but in the meantime it also opens the door to attacks on democratic institutions and to the prevention of their operation.

Keywords: internet, democracy, Muslim countries, internet usage

EgYed SzILÁRD, tanársegéd, Edutus Egyetem Gazdaságtudományi Tanszék (egyed.szilard@edutus.hu). 


\section{BEVEZETÉS}

Az iszlám államokban történő - arab tavasz utáni - demokratizálási erőfeszítések ismét aktuálissá tették a demokrácia terjedésének vizsgálatát. Az észak-afrikai és a közel-keleti eseményeket látva joggal tehetô fel a kérdés, hogy a demokrácia megjelenhet-e bárhol, és ha igen, akkor melyek azok a tényezók, amelyek a megjelenését, megerôsödését és múködóképességét biztosíthatják.

E kérdéseket sokan, sokféle módon próbálták érdemben megválaszolni. Léteznek vélemények, amelyeknek értelmében a demokrácia és a piac (piaci kapitalizmus) szoros kapcsolatban van egymással. Ezen vélemények némelyike azt állítja, hogy maga a gazdasági fejlődés (Wucherpfennig-Deutsch, 2009), vagy a fejlődés az oktatás színvonalának emelésén keresztül vezet el a demokráciához (Rowen, 1995). Más vélemények értelmében pedig a beruházások és a gazdaság növekedése segíti elő a demokrácia kialakulását és megerôsödését (Olson, 1993). Mások akként vélekednek, hogy a kapitalizmus bárhova „átültethető”, mivel az egy kultúrák felett álló rendszer. Ahol pedig a kapitalizmus meghonosodott, ott a demokrácia is megjelenik és megerôsödik majd (Zakaria, 1997).

A demokrácia és a piac ilyen közvetlen, szoros kapcsolatáról azonban kevéssé beszélhetünk (Acemoglu, 2014), ugyanis nagyszámú ellenpélda említhetô mindkét irányból. Egyrészt egyáltalán nem tekinthetjük evidenciának azt, hogy ahol jól múködik a kapitalizmus, valamint jól teljesít a gazdaság, ott demokrácia is van (vagy legalábbis lesz). Az utóbbi idôkben ennek legjobb példája Kelet-Ázsia. Az ottani (például a kínai) autoriter rezsimek legitimációja sokkal inkább a gazdasági teljesítményen alapszik, mintsem a szavazócédulákon (Jacques, 2004; Chen-Dickson, 2010:17). Miközben a másik irányból is találhatók ellenpéldák (Lipset et al., 1993).

A demokrácia korlátok és határok nélküli terjedésével kapcsolatos vizsgálatok azonban nem csak a „piac irányából” folytak. Más megközelítések az internet terjedésében látják a demokrácia térhódításának feltételét (Gilder, 1992; Kedzie, 1997; Sylvester-Bradley, 2016). Joggal tehetô fel a kérdés, hogy vajon tényleg az internet térhódítása vezet-e el a demokrácia határok nélküli terjedéséhez.

Erre a kérdésre nem egyszerú választ adni, minden kétséget kizáró módon felelni rá pedig szinte lehetetlen. Ennek ellenére azonban a cikkemben megpróbálok érdemben hozzászólni a kérdéshez. Az érdemi válasz érdekében elemzem magát a demokráciát, azon tényezőket, amelyek gátat szabhatnak terjedésének, továbbá - a demokrácia tükrében - az internetet.

\section{DEMOKRÁCI A}

\section{A demokrácia fogalma}

Napjainkban alig vannak olyanok, akik általában beszélnek a demokráciáról, a társadalomtudósok kiegészítő meghatározásokkal „bôvítik”, létrehozva így a „jelzôs” demokráciákat (pl. elit demokrácia, unitárius demokrácia, amerikai, európai vagy 
éppenséggel japán demokrácia). Jelen cikk szempontjából azonban a demokrácia kultúrafüggetlen, általános jellemzối fontosak, hiszen a tanulmány a demokrácia határok nélküli terjedésének lehetôségét vizsgálja. Az általános értelemben vett demokráciát konkrétan definiálni felettébb nehéz, ennek okán technikai oldalról közelítem meg a vizsgálat tárgyát, és ezen megközelítés elemeinek bemutatásával jellemzem magát a demokráciát.

A demokrácia elsôsorban az irányítottak egyetértésén alapszik. Ha a demokráciára ebból a szempontból tekintünk, akkor annak lényege azzal az eljárással kapcsolatos, ahogyan az átlagemberek részt vesznek a határozatok elfogadásának folyamatában (vagy legalábbis abban a folyamatban, amelynek során a késôbbi határozatok meghozóit kiválasztják). Ennek alapján a „demokrácia nem társadalmi típus, hanem korlátozottabb érvénnyel, de a politikai rendszer egy típusa” (Touraine, 1992).

Ennek fényében a demokrácia elemei:

- a vezetôi által irányított, szabad választás;

- a képviseleti jellegú, beszámolásra kötelezett kormányintézmények;

- a politikai hatalom periodikus változtathatósága, elmozdíthatósága rendezett, általánosan elfogadott eljárások segítségével;

- valamint a törvényi szabályozásnak alárendelt, állami posztokat betöltô személyek.

A technikai alapú megközelítéssel azonban az a probléma, hogy a procedurális demokrácia rendkívül ingatag és könnyen sebezhetô, ha a múködés nem egészül ki bizonyos alapvetô jelentôségú feltétellel. Sartori akként fogalmaz, hogy a választási rendszer megléte csupán a demokrácia mechanikai garanciája, a demokrácia legelemibb garanciája az, hogy a polgárok szabadon jussanak információhoz (Sartori, 1987:86-87). Természetesen a választás és az információhoz való szabad hozzáférés erôteljesen összefügg egymással, hiszen a demokrácia múködéséhez és múködtetéséhez korrekt döntéseket kell hozni, és korrekt döntések csak megfeleló információk birtokában hozhatók (Grönlund, 2007).

Ennek okán a demokrácia elemei:

- választott tisztségviselook ellenôrizzék a kormány politikai döntéseit;

- a választott tisztségviselőket sûrûn tartott, tisztességes választásokon választják meg, és ezeken a választásokon nincs helye a kényszerítésnek;

- a tisztségviselók megválasztásakor - bizonyos feltételek mellett - szinte minden felnôttnek joga van szavazni;

- szinte minden felnôttnek joga van - bizonyos feltételek mellett - kormányhivatalra jelöltetnie magát;

- a polgároknak joguk van arra, hogy - „komoly” - büntetés veszélye nélkül véleményt nyilváníthassanak minden, tágabb értelemben vett politikai ügyrôl, többek között bírálhatják a tisztségviselőket, a kormányt, a politikai rendszert, a társadalmi-gazdasági rendet és az uralkodó ideológiát;

- a polgároknak joguk van nemcsak kormányzati, hanem alternatív információforrásokat is igénybe venni, és ezek az alternatív információforrások a törvény védelme alatt állnak; 
- a polgároknak továbbá joguk van arra, hogy különféle jogaik - például a fentebb említett jogaik - valóra váltása érdekében viszonylag független társulásokat és szervezeteket hozzanak létre, mint például független politikai pártokat és érdekcsoportokat (Dahl, 1996).

Dahl meghatározásának értelmében az információkhoz való szabad hozzáférés, valamint a megfeleló információkkal való rendelkezés azonban a demokráciának nem elégséges, „csak” az egyik szükséges, elengedhetetlen feltétele.

Továbbá felettébb fontos kérdés, hogy a megszerzett információval mit akarunk, valamint mit tudunk kezdeni.

\section{A demokrácia univerzalitása}

\section{Autonómia}

A demokrácia közvetlen viszonyban van az elfogadott határozatok tartalmával, tehát nem csupán a társadalmi, politikai megvalósulásának folyamatát, hanem ennek a folyamatnak az eredményét is magában foglalja. Következésképpen a demokratikus kormányoknak olyan politikát kell folytatniuk, amely meghatározott demokratikus alapértékek megerôsítését segítik elő, pl. (polgári) szabadság, egyenlôség, jogszerúség.

Az elôzőekbôl következốn létezik a demokráciának egy, az univerzalitása szempontjából jelentôs feltétele, ez pedig az autonómia, amely mind az államtól, mind az elsôdleges (hagyományos) társadalomtól való autonómiát jelenti. Az autonómiának ez a megközelítése az egyéni szabadságjogokon alapszik, amelyet az állam garantál, és nem mellékesen meg is véd. Ez azt jelenti, hogy az irányítás önkényes (autokratikus) volta megszúnik. Ez a jellemzô bizonyos kultúrákban igencsak földcsuszamlásszerú változásokhoz vezetne (ha egyáltalán engednék megvalósulni).

\section{Konszenzus}

A demokrácia térhódításának további gátja - maga a demokrácia egyik alapja - az irányítottak közötti egyetértés, tehát a konszenzus. Ez a jellemzô azonnal két alapvetô problémát vet fel.

Az elsố mindjárt az, hogy miból is fakad a „jó”. A „demokratikus jó” az a jó, amit az egyes egyének együtt éppen aktuálisan jónak fogadnak el. Ez a - „folyamatosan megkérdőjelezett és megversenyeztetett jó” - megközelítés némely kultúra számára szentségtörés. A ,jó” ugyanis benne foglaltatik az adott szent iratban, attól eltérni nem érdemes, mert az kemény szankciókat vonhat maga után. Még mielôtt bárki azt gondolná, hogy csupán az iszlám - Koránba foglalt - szabályai megkérdôjelezhetetlenek, annak felhívom a figyelmét, hogy a középkori Európa is túzzel-vassal ragaszkodott a Biblia parancsolataihoz (megszegve emiatt néhány parancsolatot is).

A másik alapvetô probléma szoros összefüggésben áll az elsôvel, ugyanis az egyének közötti konszenzushoz szükségesek az egyes egyének mint individuumok, vala- 
mint azok racionalitása. A két probléma tehát alapvetôen összefügg egymással, ennek okán a továbbiakban együtt is kezelem óket.

A demokrácia alapvetô követelményei, az individualizmus és racionalizmus a hatalomgyakorlásnak csupán olyan formáit engedi meg, amelyek kiállják az egyén - racionalitásnak megfelelô - értékelésének próbáját, azaz állandóan kölcsönös összefüggésben vannak az individuális racionalizmussal. Ebben az esetben azonban bármely tekintély, bármely hatalom csupán megállapodás útján jöhet létre és múködhet, amelyet nem egyszer és nem örökre kötnek, hanem azt állandó egyeztetés útján a demokratikus folyamat segítségével lehet biztosítani. Természetesen a teljes nemzet felett létezô hatalmat is lehet legitimálni. Ezt a legitimitást rendszerint a hagyomány és a vallás biztosíthatja. Mint már utaltam rá, a legitimáció hagyományos és vallásos formáinak demokratikusra történô cseréje földcsuszamlásszerú változásokat indukál, mint ahogyan az történt Európa esetében is.

Persze a konszenzus jelentette kihívás azonnal más megvilágításba kerül, ha az etnikumok kérdése is bekerül a vizsgálatba. A Nyugat felettébb keveset tud az etnikai különbségekből adódó súlyos gondokról. Afrikában és Ázsiában nagy számban akadnak olyan országok, amelyek jelentôs számosságú és arányú etnikummal rendelkeznek. Ezeken a területeken a - nyugati értelemben vett - konszenzus aligha lehet alapja a demokráciának. Mivel a demokrácia nem egyéb, mint a többség politikája, a legnagyobb etnikai csoportot juttatja - szinte - korlátlan hatalomhoz. A többnemzetiségú társadalmak stabilitásához etnikai alapú konszenzusra van szükség. A nyugati értelemben vett, a többség és kisebbség fogalmain alapuló (nyugati) demokrácia pedig érzéketlen erre a problémára.

Univerzalitások egymással szemben, avagy a civilizációk összecsapása

Természetesen a demokrácia univerzalitásának nem csupán az áll az útjában, hogy egyes kultúrák (társadalmak) önmagukon belül képesek-e érdemben kezelni a demokrácia szellemisége okozta társadalmi-kulturális sokkot, hanem az is, hogy bizonyos kultúrák egyszerúen elutasítják a demokráciát, mivel az a „Nyugat terméke”. Ezen utóbbira példa az iszlám.

Hallottam már olyan nézeteket, amelyek abból indultak ki, hogy az iszlám és a Nyugat szembenállása a gyarmatosításban gyökerezik. Ez a fajta megközelítés azonban felettébb leegyszerúsíti a problémát, már csupán azért is, mert nem foglalkozik a valódi történelmi háttérrel. Alapvetố tévedés, hogy a két - nevezett - civilizáció szembenállása a gyarmatosítással kezdôdött volna. Igaz, hódítással kezdődött, csakhogy nem az európaiak „látogattak el” iszlám területekre, hanem éppen az iszlám próbálta térdre kényszeríteni Európát (erról a spanyolok, szicíliaiak tudnának mesélni, de ehhez nekünk magunknak is - a balkáni népekkel karöltve - lenne mit hozzáfúznünk).

Sokkal inkább az húzódik meg a háttérben, hogy az iszlám világ nem tudott és ma sem tud mit kezdeni saját hatalmának csökkenésével és a nyugati világ hatalmának növekedésével (Peremiczky, 2004). Továbbá az, hogy az iszlám is univerzalista magatartást tanúsít, amelyben az ummát, a teljes - mindenféle földrajzi korlátok- 
tól mentes - iszlám közösség egységét helyezi elôtérbe (valamint azt az elvet, hogy a közösségnek mindig elsôbbsége van az egyénnel szemben) (Eperjesi, 2004). Ez már önmagában is nehezen vagy egyáltalán nem leküzdhetố akadályt gördítene a demokrácia térhódításának útjába, azonban az iszlám - ezen jellemzókön túl - még egy fontos momentummal rendelkezik. Az iszlám a teokrácia legitimitásának is az elve. Az iszlám az egyetlen olyan vallás, amely képes megalapozni egy vallási autoriter, teokratikus államot (például Iránban). Az ilyen jellegú államszerkezet és államirányítás mellett demokratikus formák kialakulása felettébb esélytelennek túnik (Buruma, 2004; Ben-Meir, 2016; Menyhárt, 2017), mivel a vallási törvények mindenre kiterjednek, a tisztálkodási és étkezési szokásoktól a szexuális élet és a gazdasági tevékenységek szigorú szabályozásáig.

Az elôzóek alapján kijelenthetó, hogy vannak kultúrák, amelyek jelenlegi állapotukban nem „kompatibilisek” a demokráciával. Kérdéses persze, hogy az internet kompatibilis-e.

\section{INTERNET}

Az internet és a demokrácia „kompatibilitása”

Létezố vélemény szerint az internet maga demokratikus (Gilder, 1992), mivel biztosítja az egyéni és a csoportos függetlenséget (Clift, 2000). Egyáltalán nem biztos azonban, hogy egy ilyen kijelentéssel le lehet érdemben zárni azt a kérdést, amely a demokrácia és az internet kapcsolatának szorosságára vonatkozik.

$\mathrm{Az}$ internet - az egyéni és a csoportos függetlenségen túl - lehetôséget teremt arra, hogy a polgárok nagyobb mértékben szóljanak bele például az egészségügyet, az oktatást, a civil szervezetek múködését érintô kérdésekbe, avagy éppenséggel aktívabban vegyenek részt a lokális civil szervezetek életében (Horrigan et al., 2001). Továbbá az információs szupersztráda a társadalom által háttérbe szorított csoportok (pl. a nốk, a szegények, a kisebbségek és a segítséggel élôk) „hangjának hallatásához” könny(ebb)en hozzáférhetố csatornát biztosít.

Az elôzóeken túl a kutatók statisztikai adatokkal is igyekeztek az összefüggés meglétét bizonyítani. Kedzie például, a The Comparative Survey of Freedom kutatás módszerét és adatait felhasználva, ${ }^{1}$ kimutatta, hogy az interkonnektivitás, azaz az internet, BITnet, FidoNet és az UUCP - e-mailek küldését és fogadását lehetôvé tevố hálózatok - használata erôteljesen korrelál a demokráciával, sôt bizonyította, hogy az említett hálózatok használata erôs hatást ${ }^{2}$ gyakorol a demokráciára. Eme - 1994. évre vonatkozó adatokat felhasználó - elemzés emellett azért is figyelemre méltó, mert a vizsgálatba bevont egyéb tényezôket (mint változókat) is (pl. gazdasági fejlettség/GDP, népességszám stb.), és azt találta, hogy az összes többi tényezô hatása messze elmarad az interkonnektivitásé mögött (Kedzie, 1997).

Ma, 20 évvel késôbb az interkonnektivitás szinte kizárólag az interneten keresztül valósul meg (a BITnet már nem múködik, valamint az UUCP és a FidoNet felhasználóinak a száma messze eltörpül az interneté mögött), így ennek, valamint a korábbi- 
aknak tudatában határozottabban állíthatnánk, hogy az internet erôteljesen segíti a demokrácia kialakulását és múködését.

Ettôl eltérô következtetésre jutunk azonban, ha ismét megvizsgáljuk az interkonnektivitás ${ }^{3}$ és a demokrácia ${ }^{4}$ kapcsolatát. 197 független ország 2017. június 30-ára vonatkozó adatait felhasználva arra az eredményre jutunk, hogy - 5\%-os szignifikanciaszint mellett - az interkonnektivitásnak, azaz az internet használatának nincs szignifikáns hatása a demokráciára. Meg kell azonban jegyezni, hogy ez csupán azt jelenti, hogy egy bizonyos idôpillanatban - 2017. június 30-án - egy adott ország esetében az internetpenetráció nagysága nem befolyásolja a demokráciaértéket. Az említett időpontban - mint az 1. táblázat is mutatja - találhatunk olyan országokat, ahol viszonylag nagy az internetpenetráció, és mégis alacsony a demokráciaérték. Az azonban figyelemreméltóbb ennél, hogy olyanokat is találhatunk, amelyek esetében magas a demokráciaérték, mégis kicsi a penetráció.

1. táblázat: Alacsony demokráciaértékú és magas internetpenetrációjú, valamint magas demokráciaértékú és alacsony internetpenetrációjú országok

\begin{tabular}{l|l|c|c|c|l|c|c|c|c}
\hline Ország & IP* & DV** & PR*** & CL*** & Ország & IP* & DV** & PR*** & CL*** \\
\hline Bahrein & 98,00 & 12 & 7 & 6 & Marshall-szk. & 0,04 & 92 & 1 & 1 \\
\hline Emirátusok & 90,61 & 20 & 6 & 6 & Palau & 0,35 & 92 & 1 & 1 \\
\hline Thaiföld & 83,46 & 32 & 6 & 5 & Grenada & 0,05 & 89 & 1 & 2 \\
\hline Azerbajdzsán & 78,20 & 14 & 7 & 6 & Benin & 12,00 & 82 & 2 & 2 \\
\hline Brunei & 75,00 & 29 & 6 & 5 & Kiribati & 13,70 & 92 & 1 & 1 \\
\hline
\end{tabular}

Megjegyzés: * Az internetpenetráció teljes lakossághoz viszonyított nagysága (\%-ban); ** A demokráciaérték abszolút nagysága; *** A Politikai Jogok Indexe (PR), valamint a Polgári Szabadságjogok Indexe (CL). Forrás: Internet World Stats, 2017; Freedom in the World, 2017

Amennyiben egyéb tényezôket - pl. az egy fơre jutó GDP-t (GDP/capita), az ország területének nagyságát stb. - bevonunk a vizsgálatba, akkor azt tapasztaljuk, hogy az egy fốre jutó GDP-nek - Kedzie elemzésének eredményével szemben - van hatása a demokráciára. ${ }^{5}$

A részletesebb szemügyrevétel során azt találjuk, hogy - mint azt a 2. táblázat is mutatja - a magas egy fôre jutó GDP-vel rendelkezó országoknak magas a demokráciaértékük is, miközben a legalacsonyabb GDP/fố mutatójú államok demokráciaértéke is viszonylag alacsony.

A közel-keleti olajkitermelő iszlám államok a GDP/fố mutató magyarázóerejét gyengítik, mivel ezen országok esetében magas az említett mutató értéke (15 00059000 US\$), miközben felettébb alacsony a demokráciaérték (10-37).

A további elemzések arra világítanak rá, hogy egy adott ország demokráciaértékére - közepesen erôs - hatással van annak többségi vallása, valamint adott régióhoz, térséghez tartozása. ${ }^{6}$ A tüzetesebb vizsgálatok során azt tapasztalhatjuk, hogy - mint azt 
a 3. táblázat is mutatja - a keresztény államok átlagosan magasabb, az iszlám országok pedig alacsonyabb demokráciaértékkel rendelkeznek. (Természetesen az egyes többségi vallásokon belüli demokráciaértékek erôteljesen heterogén képet mutathatnak.)

2. táblázat: Az 5 legalacsonyabb és legmagasabb GDP/fö mutatójú ország

\begin{tabular}{l|c|c|c|c|l|c|c|c|c}
\hline Ország & GDP/fó* & DV & PR & CL & Ország & GDP/fö* & DV & PR & CL \\
\hline Burundi & 286 & 19 & 7 & 6 & Liechtenstein & 141165 & 91 & 2 & 1 \\
\hline Malawi & 301 & 63 & 3 & 3 & Luxemburg & 102831 & 98 & 1 & 1 \\
\hline Niger & 363 & 49 & 4 & 4 & Svájc & 78812 & 96 & 1 & 1 \\
\hline Mozambik & 382 & 53 & 4 & 4 & Norvégia & 70812 & 100 & 1 & 1 \\
\hline K-afrikai K. & 382 & 10 & 7 & 7 & Írország & 61606 & 96 & 1 & 1 \\
\hline
\end{tabular}

Megjegyzés: *USA-dollárban számítva.

Forrás: World Bank, 2017; Freedom in the World, 2017

Ugyanakkor meg kell jegyezni, hogy a többségi vallás esetében óvatosan kell kezelni az eredményeket, mivel az egyszerú csoportosítás nem tartalmazza az adott vallás tényleges gyakorlásának mértékét és intenzitását.

Továbbá érdekességként megemlíthetô, hogy olyan térségekben, ahol keverednek a többségi vallások, ott az egyes demokráciaértékek is heterogén képet mutatnak, azonban az adott országok - mint azt a 4. táblázat, valamint közvetve a 3. táblázat is mutatja - inkább a régiójukba tartozó egyéb államokhoz hasonlítanak, mint az egyéb régiókba tartozó, de azonos többségi vallásúakhoz. ${ }^{7}$

Mind Kedzie, mind pedig az általam elvégzett elemzések módszerével alapvetô problémák vannak, ugyanis amíg a bemutatott eredmények egy adott idôpillanatra vonatkoznak, addig a demokrácia kialakulása folyamatok eredménye, továbbá a demokrácia múködése és múködtetése maga is folyamat. Ennek okán vizsgáltam, hogy az internethasználat terjedése, a penetráció növekedése miként hat a demokráciaérték változására. Ennek okán úgy döntöttem, hogy - a 2007. június 30. és 2017. június 30. közötti - tízéves idôintervallum penetrációnövekedéseinek ugyanezen idôszak demokráciaérték-változásaira kifejtett hatását vizsgálom. A vizsgálat elvégzése arra az eredményre vezetett, hogy - 5\%-os szignifikanciaszint mellett - nincs hatása az internethasználat terjedésének a demokráciára. ${ }^{8}$

Amennyiben azonban - a korábbiak ellenére - mégis kijelentjük, hogy az internethasználat meghatározza a demokrácia „milyenségét”, akkor azonnal adja magát a kérdés, hogy ez vajon mely folyamatokon keresztül, hogyan megy végbe. A kiindulópont a lakossági internethasználat, azaz az információs sztráda igénybevétele kialakítja és fenntartja a polgárság demokratikus irányultságát (egyrészt óhajtják a demokrácia intézményrendszerének meglétét, és annak múködésében, múködtetésében aktívan részt is kívánnak venni). Amennyiben ez megvalósul, akkor a polgárok nyomást gyakorolnak a vezetôikre, hogy azok hozzák létre a demokrácia intézmény- 
3. táblázat: A 10 legdemokratikusabb, valamint legkevésbé demokratikus keresztény és iszlám ország

\begin{tabular}{l|c|c|c|c|l|c|c|c|c}
\hline \multicolumn{1}{c|}{ Ország* } & Régió & $\mathbf{D V}$ & $\mathbf{P R}$ & $\mathbf{C L}$ & Ország** & Régió & DV & PR & CL \\
\hline ÁTLAG*** & & $\mathbf{7 1 , 0 1}$ & $\mathbf{2 , 6 9}$ & $\mathbf{2 , 6 0}$ & ÁTLAG**** & & $\mathbf{3 3 , 2 4}$ & $\mathbf{5 , 2 2}$ & $\mathbf{5 , 0 6}$ \\
\hline Norvégia & Európa & 100 & 1 & 1 & Tunézia & Afrika & 76 & 2 & 2 \\
\hline Svédország & EU & 100 & 1 & 1 & Szenegál & Afrika & 74 & 2 & 2 \\
\hline Finnország & EU & 100 & 1 & 1 & Indonézia & Ázsia & 65 & 2 & 3 \\
\hline Hollandia & EU & 99 & 1 & 1 & Burkina Faso & Afrika & 65 & 3 & 3 \\
\hline Kanada & É-Amerika & 99 & 1 & 1 & Sierra Leone & Afrika & 64 & 3 & 3 \\
\hline Luxemburg & EU & 98 & 1 & 1 & Tanzánia & Afrika & 64 & 3 & 3 \\
\hline Ausztrália & Ausz. és Óc. & 98 & 1 & 1 & Comore-szk. & Afrika & 60 & 4 & 3 \\
\hline Új-Zéland & Ausz. és Óc. & 98 & 1 & 1 & Elefántcsontp. & Afrika & 58 & 4 & 3 \\
\hline Uruguay & D-Amerika & 98 & 1 & 1 & Szingapúr & Ázsia & 54 & 4 & 4 \\
\hline Izland & Európa & 97 & 1 & 1 & Nigéria & Afrika & 53 & 5 & 3 \\
\hline Venezuela & D-Amerika & 20 & 7 & 5 & Líbia & Afrika & 13 & 7 & 6 \\
\hline Oroszország & Európa & 20 & 7 & 6 & Bahrein & Közel-Kelet & 12 & 7 & 6 \\
\hline Belarusz & Európa & 20 & 7 & 6 & Tádzsikisztán & Ázsia & 11 & 7 & 6 \\
\hline Kongói DK & Afrika & 19 & 7 & 6 & Szaúd-Arábia & Közel-Kelet & 10 & 7 & 7 \\
\hline Burundi & Afrika & 19 & 7 & 6 & Szudán & Afrika & 6 & 7 & 7 \\
\hline Szváziföld & Afrika & 18 & 7 & 5 & Szomália & Afrika & 5 & 7 & 7 \\
\hline Kuba & Karib-térség & 15 & 7 & 6 & Dél-Szudán & Afrika & 4 & 7 & 7 \\
\hline Etiópia & Afrika & 12 & 7 & 6 & Türkmenisztán & Ázsia & 3 & 7 & 7 \\
\hline E. Guinea & Afrika & 8 & 7 & 7 & Üzbegisztán & Ázsia & 3 & 7 & 7 \\
\hline Eritrea & Afrika & 3 & 7 & 7 & Szíria & Közel-Kelet & 1 & 7 & 7 \\
\hline & & & & & & & \\
\hline
\end{tabular}

Megjegyzés: * keresztény államok; ** iszlám államok; *** N=124; **** N=51

Forrás: Internet World Stats, 2017; Freedom in the World, 2017

\section{4. táblázat: Az afrikai régióba tartozó 8 leginkább demokratikus állam többségi vallása}

\begin{tabular}{l|c|c|c|c|l|c|c|c|c}
\hline \multicolumn{1}{c|}{ Ország } & Vallás & DV & PR & CL & Ország & Vallás & DV & PR & CL \\
\hline Cape Verde & keresztény & 90 & 1 & 1 & Sao Tomé & keresztény & 81 & 2 & 2 \\
\hline Mauritius & hindu & 89 & 1 & 2 & D-afrikai K. & keresztény & 78 & 2 & 2 \\
\hline Ghána & keresztény & 83 & 1 & 2 & Tunézia & iszlám & 78 & 1 & 3 \\
\hline Benin & természeti & 82 & 2 & 2 & Szenegál & iszlám & 78 & 2 & 2 \\
\hline
\end{tabular}

Forrás: Internet World Stats, 2017; Freedom in the World, 2017 
rendszerét (azokon a területeken, ahol odáig az intézményrendszer nem létezett), valamint érdemben múködtessék is azt. Tehát presszionálják a vezetôket, hogy azok teremtsék meg a lakosság számára a jogokkal való élés feltételeit (ami után a polgárok pedig élni is fognak a jogaikkal). Ez a folyamat azonban azonnal néhány felettébb izgalmas kérdést vet fel.

\section{A demokratizálás ,anyagi” korlátai}

Hiába vannak meg a demokrácia múködését biztosító intézmények, a választók aktív részvétele nélkül nem beszélhetünk demokráciáról. Legalábbis múködôképesről nem.

Ezt az internet és a demokrácia összefüggésében lefordíthatjuk úgy is, hogy amenynyiben az internet maga képes lenne is demokratizálni, de a polgárok nem élnek az internet adta lehetôségekkel (sốt nem is használják az internetet), akkor az internet nem demokratizál (vagy legalábbis nem járul hozzá a demokrácia kialakulásához, illetve múködéséhez).

Ennek tükrében kijelenthetô, hogy az információs sztráda demokratizáló ereje korlátos, mivel az internetelérés maga is az. A korlátosság mögött több ok is meghúzódik. Az egyik alapvetố ok az internethasználatra alkalmas eszközök (pl. PC-k, notebookok, okostelefonok stb.) elterjedtsége. Léteznek olyan társadalmi csoportok (némely társadalom esetén túlsúlyban is akár), amelyek képtelenek megfizetni ezeket az eszközöket. Továbbá az internethez való hozzáférés szintén kérdéses, miközben gondot okozhat az említett eszközök, illetve az internet használatát biztosító ismeretek hiánya (Salgado, 2014:29; Wijesiriwardena, 2017).

\section{A demokratizálás pszichikai korlátai}

Az internet demokratizáló erejét nem csupán az „anyagi” korlátok szúkítik be, hanem az információs sztráda egyes egyénekre gyakorolt pszichikai hatásai is. Nem szabad elfelejteni, hogy az online életünkbe az offline-ból lépünk be, így visszük oda magunkkal emberi mivoltunkból adódó jellemzôinket, kulturális hátterünket, meglévô, aktuális értékrendünket. Ezeknek megfelelóen bizonyos társasághoz, csoporthoz tartozni vágyásunkat is. Amennyiben bizonyos csoportba szeretnénk tartozni, akkor a csoport szociális nyomásának hatására olyan véleményeket is támogatni fogunk, amelyek számunkra akár alapvetốen irracionálisak lehetnek (Asch, 1955). A konformitásnak vannak különbözó fajtái: a behódolás, alkalmazkodás; ${ }^{9}$ az identifikáció ${ }^{10}$ (azonosulás); valamint az internalizáción ${ }^{11}$ (Hofmeister-Tóth, 2003:98). A csoportnormákhoz való igazodás, az azonosulás az internetes fórumokon is megfigyelhetô. Ezeket a fórumokat az aktuális normák, valamint a normák betartása, meg nem szegése tartja múködésben. Egy adott fórumon belül a normasértô magatartások „elszaporodása”, „elharapódzása” a fórum összeomlásához, atomjaira hullásához és megszúnéséhez vezet el.

Amennyiben egy adott internetes csoport tagjai kívánunk lenni, úgy a csoportba belépve azonosulunk a fennálló normákkal, elôször elfogadjuk, majd pedig magunkévá tesszük azokat (Wallace, 2002:107). A csoportnormákhoz való igazodás, azok- 
kal való azonosulás azonban a csoportpolarizációt erôsíti, így éppen a demokrácia ellen hat.

A csoport polarizálódásának hátterében az húzódik meg, hogy egyrészt az emberek a kisebb ellenállás felé fordulnak, így a nézetükkel (nagyon) ellentétes véleménnyel bíró fórumokat, csoportokat kerülik (Sunstein, 2001; Boxell et al., 2017). Az internet nem csupán a „megszólaló”, hanem a „hallgató” szabadságát is biztosítja. Szemtôl szemben, tehát fizikai értelemben vett kontaktus esetén az ellentétes véleménnyel rendelkezók kevésbé kerülhetik el a vitát, mint az internetes forma esetében. Ezen utóbbinál egy klikkel elintézhetjük a kényelmetlennek ígérkezô, esetleg kényelmetlenné váló beszélgetést. A 2004-es amerikai elnökválasztás után jelentős számú demokrata tette fel a kérdést, hogyan lehetséges, hogy egy olyan jelöltet választott meg Amerika, akire egyetlen barátjuk sem szavazott, továbbá akit az általuk olvasott lapok is csak kritikával illettek (Leonard, 2004). A demokrata érzületûek szinte kizárólag hasonszôrú demokratákkal érintkeztek, valamint csupán liberális internetes magazinokat olvastak. Akárhova is fordultak, mindenhol csak saját nézeteik megerôsítésével találkoztak. Nem múködött jól az internetes nyilvánosság, mivel kevés volt az olyan fórum, ahol a különbözô vélemények és nézetek érdemi vitában ütközhettek volna (Pogonyi, 2006).

Másrészt azon személyek, akik a csoport tagjai kívánnak maradni, azonban bármilyen ellenvéleménnyel rendelkeznek, avagy olyan információk birtokában vannak, amelyek a fennálló „közös” vélemény igazságát cáfolnák, a csoport többi tagjával nem osztják meg azokat (Wallace, 2002:109). Ezeknek okán az érdemi viták, valamint a mérsékelt hangok eltû́nnek (Shirky, 1995), és a szélsôséges „hangok” egyre gyakoribbak lesznek.

Azon társadalmakban, ahol nagyobb tere van az individualizmusnak, és az egyén könnyebben helyezkedhet szembe a csoportnormákkal, ott a polarizáció csökken (Spears et al., 1990), tehát azokban a kultúrákban, amelyek a kollektivizmus fensóbbségét hirdetik (például az iszlám, valamint a kínai univerzizmus esetében), az internet a polarizáció növekedéséhez vezethet el.

Ugyanakkor a párbeszéd nem csupán az egyes táborok között csökkenhet, hanem redukálódhat az egyes oldalakon belül is. Ennek oka a (politikai) trollok és azok kommunikációs térhódítása. A (politikai) troll olyan személy, aki az online beszélgetések (pl. bloghozzászólások) azon résztvevôje, akinek a valódi célja a beszélgetés, az érdemi vita és a közösség bomlasztása és/vagy konfliktus kiprovokálása.

A politikai trolloknak alapvetôen három csoportját lehet megkülönböztetni: kommenthuszár, aki nem igazi troll, csupán az egyéni frusztrációját, illetve az agresszióját vezeti le a hozzászólásokban; a bérkommentelő, aki szintén nem igazi troll, ôt ugyanis a politika vezérli (és fizetést kap a tevékenységéért); valamint az igazi troll (Nagy, 2017).

Ugyanakkor a nyugati demokráciák számára intô jel lehet, hogy a kommunikációt túlterhelő és közösségeket szétbomlasztó trollkodás térhódítása éppen a politikai korrektség következménye, ugyanis annak ellenpontjaként, azzal vitába szállva „szökkent szárba” (Stein, 2016; Benko, 2017).

Amennyiben a trollkodás romboló hatását a trollkodás közvetlen adataival jellemezzük, akkor kijelenthetô, hogy a nyugati demokráciák súlyos problémával állnak 
szemben, ugyanis egy 2017-es, Egyesült Államokat tekintve reprezentatív kutatás eredményei szerint a nyilvános online kommunikáció (pl. kommentelés) résztvevőinek 6\%-a vallotta magát trollnak. Továbbá az összes résztvevố 41\%-a vált zaklatás áldozatává, akiknek 32\%-a a zaklatás hatására be is fejezte az adott csatornán a kommunikációt. A kutatás szerint $14 \%$ azok aránya, akiket kifejezetten politikai nézeteik miatt zaklattak, miközben a politikai oldalak egyike sem vádolhatja a másikat a kialakult helyzetért, ugyanis a politikai nézeteik miatt zaklatott személyek aránya megegyezik minden egyes politikai oldal szimpatizánsai között (Duggan, 2017).

Ugyanakkor a pszichikai korlátok esetében (is) indokolt a feltételes mód, mivel egyes kutatások arra az eredményre vezettek, hogy az internet nem feltétlenül vezet el az ellentétes véleménnyel rendelkezôk párbeszédének megszúnéséhez, valamint a nézetek radikalizálódásához.

A demokrácia szempontjából azonban aggasztó jelenség lehet - a polarizáción és a trollkodáson túl - az is, ha a választók egyre kevésbé vagy egyáltalán nem kívánnak élni demokratikus jogaikkal. Az „internetoptimisták” szerint erre is megoldást kínál a net, mivel elôsegíti a megfeleló információkkal való ellátottságot, valamint a - politikai értelemben - releváns aktivitások, tevékenységek megvalósítását. A nethasználat szempontjából legaktívabb korcsoport - a legfeljebb 25 évesek csoportja - esetében azonban a hagyományos politikai szerepvállalás (pl. választáson való részvétel, közremúködés a politikai szervezetek munkájában stb.) folyamatos csökkenést mutat. Példaként említhetô, hogy 1999 és 2013 között - 27 európai államot érintố kutatás eredményei szerint - 70\%-ról 56\%-ra csökkent a parlamenti választásokon részt vevô, legfeljebb 25 éves, választásra jogosult személyek aránya (Fieldhouse-Tranmer-Russell, 2007; Flash Eurobarometer 375, 2013). Ez az arány 2016-ra tovább csökkent (Sloam, 2016). Továbbá eme csoport választásokkal és választási lehetôségekkel kapcsolatos politikai ismeretei nem haladták meg az egyéb csoportokét, így kijelenthetô, hogy az internet használata nem eredményez nagyobb politikai tudást (Dimitrova et al., 2011, Richey-Zhu, 2015). Ugyanakkor megállapítható, hogy a hagyományos politikai szerepvállalás ilyen mértékú csökkenése mögött nem az internet terjedése, hanem a politikusokkal, politikai szervezettekkel szembeni elégedetlenség és elutasítás húzódik meg (Kézdi, 2016).

A részvételi demokráciák számára nagy kihívást jelent, hogy amíg az említett korcsoport a hagyományos politikai szerepvállalást tekintve egyre inaktívabb, addig nagyon is erôteljes - és folyamatosan erősödô - politikai aktivitást mutat. Csupán eme aktivitás a hagyományostól eltérô tevékenységek megvalósítását jelenti (pl. politikai tartalmak: hírek, képek, videók stb. online közzététele, megosztása, politikai témákhoz történố online hozzászólás, azok megvitatása stb.). Továbbá ezen politikai tevékenységek terepét fóként a social media site-ok és a politikai témájú blogok jelentik (Calenda-Meijer, 2009; Cohen-Kahne, 2012; OSCE, 2015; Ember, 2017). Továbbá az arab tavasz és néhány nyugat-európai esemény arra világít rá, hogy ez az új típusú politikai aktivitás nem csupán virtuális, hanem kifejezetten fizikai is lehet (az arab tavasz esetében ez az addig fennálló struktúrák szétzúzásához is hozzájárult).

A részvételi demokráciák számára nagy kihívást jelent ez az új típusú politikai szerepvállalás, ugyanis a fiatalok aktívak ugyan, de elutasítják a jelenlegi politikai szerep- 
lôket. Ezért kifejezetten fontos kérdés, hogy kik lesznek azok, akik képesek lesznek érdemben megszólítani ôket.

A szabadság árnyoldalai, avagy szélsôségek a neten

Az internet jelentette szabadságot olyan szervezetek és szervezódések is ki tudják használni, amelyek éppen antidemokratikus elveket vallanak. Az Egyesült Államokban például 1998-ban kétezer fasiszta ideológiájú weboldal múködött (Lassányi, 1999), ezek száma folyamatosan emelkedik. Németország 2001-ben letiltotta a neonáci tartalmú oldalak elérését, azonban - élve az internet adta lehetôségekkel - ezeket az oldalakat átköltöztették az Egyesült Államokban található szerverekre, így a német szabályozás alól kikerültek (Gyurkity, 2004). Ezek a - szélsôjobb - szervezetek az interneten keresztül toborozzák tagjaikat, valamint szervezik „életüket”. A lehetôség erre hazánkban is adott, mivel a social media site-ok felettébb könnyen használhatók csoportos cselekmények megszervezésére, ugyanis a rendészeti szervek tiszteletben kívánják tartani a tagok magánszféráját, így nem ellenôrzik az üzeneteket.

Természetesen a demokráciára nem csupán a szélsôjobb (és szélsôbal) ideológiák internetes terjedése jelent veszélyt, hanem a terrorizmus is. A globális hozzáférés a terrorizmus nemzetközivé szélesedését hozta magával. 1997-ben még csupán 12 terrorista weboldalt tartottak nyilván, 2005-ben már 5000 és 10000 közé tették ezen oldalak számát (Coll-Glasser, 2005), miközben 2016-ban már hetente (!) kapcsoltak le a hatóságok 1000, ISIS-hez köthetô weboldalt és közösségi médiabeli felhasználói fiókot (Robson, 2016).

További probléma, hogy az internet nemcsak globális kommunikációs csatornát biztosít, valamint nem csupán a fizikai kontaktust teszi nélkülözhetôvé a terroristák és terrorista csoportok között, de a kereskedelmi forgalomban beszerezhetô anyagokból és eszközökből összeállítható robbanószerek és -szerkezetek elkészítésére vonatkozó kézikönyveivel lényegében kiiktathatóvá teszi a hagyományos illegális fegyver- és robbanószer-kereskedelmet is (Tálas, 2005; Kohlmann, 2006; Bentley et al., 2017).

Ugyanakkor az internet nem csupán kommunikációs megoldást biztosít a terroristák számára, hanem konkrétan magát az eszközt is. Eme utóbbi esetében beszélhetünk kiberterrorizmusról. A fejlett államok gazdasági, szociális, egészségügyi és demokratikus intézményi rendszerének múködéséhez ma már elengedhetetlen az online platformok használata. Könnyen belátható, hogy eme platformok múködésének ellehetetlenítése milyen csapást jelentene az adott demokráciáknak. (Ma már közhelyszámba megy, hogy nagyobb kárt tud okozni egy online támadás, mint egy fizikailag elkövetett terrorcselekmény.) Ugyanakkor napjainkban (még) képesek a biztonsági rendszerek megelôzni, illetve minimális szinten tartani a sikeres kiberterrorista támadásokat (Oriti, 2017; Palmer, 2017).

Eddig azon „szerencsés” helyzettel foglalkoztam, hogy ha a lakosság óhajtja a demokráciát, akkor demokrácia is lesz. Mint a korábbiakból kitúnt, az információs sztráda használata még nem garantálja azt, hogy a felhasználó akarja is a demokráciát (a demokrácia intézményrendszerét és/vagy a múködésében, múködtetésében való 
aktív részvételt). Felmerül azonban a kérdés, hogy mi a helyzet akkor, ha a demokrácia vezetôi ellenállásba ütközik.

„INTERNETALAPÚ” DEMOKRÁCIA AZ ISZLÁM ORSZÁGOKBAN?

Az iszlám országok internethasználata

Egyes kutatók arra hívják fel a figyelmet, hogy jelenleg az iszlám országokban terjed legnagyobb mértékben a lakossági internethasználat. Az összes - mintában szereplő felhasználó és lakos figyelembevételével azt mondhatjuk, hogy 2000. december 31. és 2017. június 30. között átlagosan 58,7-szeresére nőtt az információs sztráda nyújtotta lehetôségekkel élốk aránya, aminek következtében - ahogyan azt a 5. táblázat is mutatja - alig vagy egyáltalán nem maradnak el a penetráció esetében a világ élmezônyétôl.

5. táblázat: A 10 legnagyobb internetpenetrációval rendelkezố iszlám és egyéb többségi vallású állam

\begin{tabular}{l|c|l|c}
\hline \multicolumn{1}{c|}{ Ország* } & IP** & \multicolumn{1}{c}{ Ország**** } & IP** \\
\hline Bahrein & 98,00 & Izland & 100,00 \\
\hline Katar & 94,29 & Norvégia & 99,65 \\
\hline Emirátusok & 90,61 & Liechtenstein & 98,08 \\
\hline Szingapúr & 81,24 & Andorra & 97,93 \\
\hline Jordánia & 79,98 & Luxemburg & 97,49 \\
\hline Comore-szigetek & 79,40 & Dánia & 96,90 \\
\hline Malajzia & 78,79 & Monaco & 95,21 \\
\hline Kuvait & 78,40 & Hollandia & 94,78 \\
\hline Azerbajdzsán & 78,20 & UK & 94,74 \\
\hline Kazahsztán & 76,80 & Japán & 93,98 \\
\hline
\end{tabular}

Megjegyzés: * Iszlám országok; ** internetpenetráció mértéke 2017. június 30-án (\%-ban); *** internetpenetráció növekedése 2000. december 31. és 2017. június 30. között (\%-ban); **** nem iszlám országok Forrás: Internet World Stats, 2017

Természetesen ez a szédületes növekedés nem hagyta érintetlenül az addig fennálló politikai struktúrákat (sem). A 21. század elsô évtizede robbanásszerú változásokat hozott az internethasználat területén a MENA (Közel-Kelet és Észak-Afrika) régióban, és ezek a változások jelentősen hozzájárultak a régió lángra lobbanásában, ami az „arab tavasz” néven vonult be a történelembe. Amíg az évtized legelején a nethasználók fooként értelmiségiek (üzletemberek, felsôfokú oktatási intézmények tanárai és hallgatói) voltak, akik leggyakrabban a munkahelyükön, a felsôoktatási intézményekben, valamint a netkávézókban neteztek (Teitelbaum, 2002), addig az évtized végére 
- a robbanásszerú felhasználószám-növekedés okán - minden társadalmi csoportban megjelent a nethasználat, ami a közösségi terekrôl áttevôdött a felhasználók otthonába (Sajbl, 2012). Ez önmagában hatalmas változást mutat, azonban a politikai struktúrák szétzúzásához sokkal inkább a felhasználás módjának változása vezetett el. Ugyanis amíg az évtized második harmadáig a személyes (vagy személyesnek hitt) nethasználat során leginkább chateltek a felhasználók (többnyire ellentétes nemúekkel, ennek megfelelóen sokkal inkább a szexualitás volt a téma, mintsem a vallás vagy a politika) (Wheeler, 2006), addig az évtized végére - akárcsak a nyugati demokráciákban - a social media site-okon (és abban is fóként a Facebookon) megvalósított aktivitások váltak jellemzôvé (DSG, 2011). Eme aktivitások között pedig számottevô szerepet játszottak a politikai hírek megosztása és megvitatása (az addig fennálló politikai rendszerek ellenôrzési tevékenységének köszönhetôen más csatornákon ez nem is nagyon valósulhatott volna meg) (Ghannam, 2011:12-13).

A hírek „terjesztésének” hatására a nethasználók határozott, és ami ennél is fontosabb, saját véleménnyel viseltettek a szúkebb (és a tágabb) környezetüket érintô kérdésekben. Végeredményben pedig kijelenthetô, hogy az internethasználók körében is kialakult a szabadság és a (szabad) választás iránti vágy.

Amennyiben ezt elfogadjuk, akkor megvalósult az, ami az internet demokratizáló folyamatának elsố lépése, azaz az információs sztráda megteremti a felhasználókban a demokrácia intézményrendszere, valamint a demokrácia múködésében és múködtetésében való aktív részvétel iránti vágyat.

Ezzel azonban felmerül két további kérdés: egyrészt, hogy a fentiekból ténylegesen következik-e, hogy a társadalom akarja a demokráciát, és múködésében, múködtetésében aktívan részt is kíván venni, másrészt az igenlố válasz esetén a „közös társadalmi” óhaj és akarat elegendô lesz a demokrácia kialakulásához és sikeres múködéséhez. Hiszen nem sokat ér az egyes személyek óhaja, ha a környezet maga antidemokratikus. Avagy úgy is megfogalmazható, hogy nem sokat ér a demokrácia iránti vágy és az ellenőrizetlen online kommunikáció, ha az offline élet minden egyéb pillanatában ellenőrzik az egyént.

\section{„Internetalapú” iszlám demokrácia (vezetôi) korlátai}

Az arab tavasz rávilágított, hogy az iszlám országok lakossága szabad(abb) világban kíván élni, azonban ez egyáltalán nem azt jelenti, hogy ez a szabad (abb) élet a demokráciát jelenti. Arról nem is beszélve, hogy az iszlám országok jelenlegi vezetôi bebizonyították, hogy jóval kevésbé támogatják a múködôképes demokráciát, mint ahogyan azt a (nyugati) világgal próbálták/próbálják elhitetni.

A MENA-országokat jellemzô demokráciamutatók stagnáló értékeinek - és romló megítélésének - hátterében éppen az internethasználat terjedése húzódik meg, ugyanis az információs sztráda növekvô lakossági igénybevétele okán az iszlám országok vezetôi egyre kiterjedtebben kívánják ellenôrizni a netet és a neten megvalósított kommunikációt. Úgy is lehet fogalmazni, hogy a jelenlegi vezetôk tanultak az arab tavaszhoz vezetô - online - folyamatokból. Ennek okán kijelenthetô, hogy a szabadság 
iránti vágy nem vezetett el a szabadsághoz, ugyanis már egy, a regnáló rezsimnek nem tetszố tweet miatt is börtönbe lehet kerülni (Farid, 2015; Moussa, 2016).

Kijelenthetô tehát, hogy az iszlám országok vezetői olyan magatartást tanúsítanak, amelyek a saját hatalmuk megszilárdítását és fenntartását célozzák, így a demokrácia kialakulása (vagy legalábbis térhódítása) ellen hatnak. Az „internetalapú” iszlám demokrácia korlátainak figyelembevétele után kimondhatjuk, hogy rövid(ebb) idôtávon belül az információs sztrádának marginális a demokratizáló ereje.

\section{Öss ZEGZÉs}

Kijelenthetô, hogy az internet sem demokráciabarát, sem pedig demokráciaellenes. Az információs sztráda ugyanis csupán egy eszköz, egy lehetôség. Nagy lehetôség ugyan, de akkor is csak lehetôség. Nem több. Lehetôség a „megszólalás” egy újabb, akár nagyobb elérést biztosító módjára, de azt egyáltalán nem garantálja, hogy ezt az újabb módot, újabb csatornát használni is fogják. Egymásról érdemben tudomást nem vevô csoportokra, vagy éppenséggel egy atomjaira bomlott társadalomból a nethasználat terjedésével sem lesz egykettôre „internetalapú” demokrácia.

Emellett az internet lehetôség az antidemokratikus tevékenységek megtervezésére, megszervezésére és végrehajtására. Emellett lehetôség az érdemi viták kerülésére. Olyan polgári társadalomban azonban, amelyben léteznek „közös” ügyek, és ezeket az ügyeket nyilvánosan vitatják meg, továbbá az állampolgárok részt is kívánnak venni a közügyekben, valamint a demokrácia intézményrendszerének múködésében, múködtetésében, a nethasználat terjedésével sem szúnik meg a demokrácia. Továbbá a jelenlegi „érinthetetlen igazságok” szabad és széles körú vitathatóságához és vitájához sem vezet el a lakossági internethasználat terjedése. Legalábbis rövid idôtávon.

Hosszabb idôtávon azonban egészen más lehet a helyzet. Az internethasználat „fellazíthatja” az uralkodó gondolkodásmódot, és elvezethet a jelenleg még fennálló, „érinthetetlen” igazságok széles körú és szabad kritikájához. Európának is megvoltak a saját, „érinthetetlen” igazságai, amelyeket azóta már szabadon, széleskörúen lehet kritizálni, sốt helyettük más dolgokat elfogadni igaznak. Természetesen ez a folyamat Európában sem egyik napról a másikra ment végbe.

Tehát, amíg napjaink „érinthetetlen” igazságait szabadon lehet kritizálni, addig sok víz lefolyik még a Dunán, akarom mondani, az Eufráteszen.

\section{JEGYZETEK}

1 A demokráciaérték maximálisan 100 pont, amelybôl 40 pont a politikai jogok, 60 pedig a polgári szabadságjogok részértékeinek az összege. A politikai jogokat 9 szempont (pl. szabad és fair választás, decentralizált politikai hatalom, mindenféle autoritástól mentes polgárság stb.), a polgári szabadságjogokat pedig 13 szempont (pl. szabad és független média, gyülekezési szabadság, nyitott közbeszéd, szabad magánvélemény stb.) alapján értékelik. A demokráciaérték nagysága egyenes arányban áll a demokrácia pozitív megítélésével. A politikai jogok és a polgári szabadságjogok értékének abszolút nagyságából képeznek hétfokú skálán mért indexeket (Polgári Szabadságjogok Indexét, valamint a Politikai Jogok Indexét, ahol 1: teljesen szabad, teljesen demokratikus; 7: egyáltalán nem szabad, egyáltalán nem demokratikus) (Ryan, 1993). 


\section{Polgári Szemle · 14. évfolyam 1-3. szám}

2 Demokráciaérték (DÉ) függô, valamint interkonnektivitás (IK), GDP, lakosságszám (LSZ) független változók esetén 5\%-os szign. szinten $\left(\mathrm{X}^{2}=0,536\right)$ a modell: $\mathrm{DE}=36,1+5,57 \mathrm{IK}-3,48 \mathrm{LSZ}(\mathrm{N}=237)$ (GDP nem szign.).

3 Kedzie-tôl eltérốen az egyes országokra vonatkozó interkonnektivitást - mivel azt csupán az internet használatán keresztül mérem - nem az országok egymáshoz viszonyított penetrációs rangszámával, hanem az adott ország penetrációs arányszámának nagyságával jellemzem.

4 A vizsgálatba bevont Freedom in the World 2017 és World Audit Democracy Profile 2007 a már említett - The Comparative Survey of Freedom - kutatáséval azonos módszerrel számítja a demokráciaértéket (DV), valamint a Politikai Jogok Indexét (PR) és a Polgári Szabadságjogok Indexét (CL).

$5 \quad \mathrm{R}^{2}=0,175$ (közepesen erôs magyarázó erô), a regressziós modell: DÉ $=52,06+0,001 \mathrm{GDP} / \mathrm{capita}(\mathrm{N}=194)$ (a többi változó hatása - 5\%-os szignifikanciaszint mellett - nem szignifikáns).

${ }^{6}$ A többségi vallást egy adott ország területén élők vallási megoszlása határozza meg (lehet keresztény, iszlám, buddhista, hindu, esetleg természeti). A jellemzô térség, régió az, amelyikbe tartozik az adott ország (lehet Afrika, Észak-Amerika, Karib-térség, Mexikó és Közép-Amerika, Dél-Amerika, Ausztrália és Óceánia, Közel-Kelet, Ázsia a Közel-Kelet nélkül, Európai Unió, valamint Európa az Európai Unió nélkül). $\eta^{2}=0,307$ a vallás $(\mathrm{N}=193), \eta^{2}=0,459$ a jellemzô térség, régió $(\mathrm{N}=197)$ esetében. Az adott állam többségi vallása és jellemzố térséghez tartozása nagyon szoros kapcsolatot mutat $\left(\mathrm{X}^{2}=164\right.$, szignifikancia: 0,000$)$.

7 Emiatt - is - erôsebb az adott régió hatása, mint a többségi vallásé.

8 A demokráciaérték változásának abszolút nagyságán túl a változás irányára sincs - 5\%-os szignifikanciaszint mellett - hatással az internethasználat terjedése.

9 A kívánt magatartásminta a külsô kényszer hatására jön létre, és csupán a külsô kényszer meglétéig áll fenn.

10 Az adott egyén értékrendje nem egyezik a fennálló (külsô) értékrenddel, de azt belsô indíttatás hatására folyamatosan magáévá teszi.

11 Az adott egyén értékrendje teljesen megegyezik a fennálló (külsô) értékrenddel.

\section{FELHASZNÁLT IRODALOM}

Acemoglu, Daron (2014): Does Democracy Boost Economic Growth? World Economic Forum, May 20, www. weforum.org/agenda/2014/05/democracy-boost-economic-growth/.

Asch, Solomon E. (1955): Opinions and Social Pressure. Scientific American, Vol. 193, No. 5, 31-35, https:// doi.org/10.1038/scientificamerican1155-31.

Benko, Ralph (2017): Trigger Warning, How the Trolls Occupied Politics and What to Do About It. Forbes, June 30, www.forbes.com/sites/ralphbenko/2017/06/30/trigger-warning-how-the-trolls-occupied-politics-and-what-to-do-about-it/\#53b6ac29bdfa.

Ben-Meir, Alon (2016): Is Islam Compatible With Democracy? Huffington Post, January 24.

Bentley, Paul - Keough, Glen - Greenhill, Sam (2017): Jihadi Terror Manuals on How to Use a Car As a 'Tool of War' for Mass Murder Can Be Found in Just Two Minutes on Google and Twitter. Daily Mail, March 23.

Boxell, Levi - Gentzkow, Matthew - Shapiro, Jesse M. (2017): Is the Internet Causing Political Polarization? NBER Working Paper, No. 23258, https://doi.org/10.3386/w23258.

Buruma, Ian (2004): An Islamic Democracy for Iraq? The New York Times, December 6, www.nytimes. com/2004/12/05/magazine/an-islamic-democracy-for-iraq.html.

Calenda, Davide - Meijer, Albert (2009): Young People, the Internet and Political Participation. Information, Communication and Society, Vol. 12, No 6, https://doi.org/10.1080/13691180802158508.

Chen, Jie - Dickson, Bruce J. (2010): Allies of the State. China's Private Entrepreneurs and Democratic Change. Harvard University Press, Massachusetts.

Clift, Steven (2000): An Internet of Democracy. Communications of the ACM, Vol. 43, No. 11, https://doi. org/10.1145/353360.353376.

Cohen, Cathy - Kahne, Joseph (2012): Social Media Powers Youth Participation in Politics. ScienceDaily, June 26. 


\section{Egyed Szilárd: Az internet demokratizáló hatása}

Coll, Steve - Glasser, Susan B. (2005): Terrorists Turn to the Web as Base of Operation. Washington Post, August 7, www.washingtonpost.com/wp-dyn/content/article/2005/08/05/AR2005080501138.html.

Dahl, Robert A. (1996): A pluralista demokrácia dilemmái. Osiris Kiadó, Budapest.

Dimitrova, Daniela V. - Shehata, Adam - Strömbäck, Jesper (2011): The Effects of Digital Media on Political Knowledge and Participation in Election Campaigns. Communication Research, Vol. 41, No. 1, https:// doi.org/10.1177/0093650211426004.

DSG (2011): Facebook Usage: Factors and Analysis. Arab Social Media Report, Vol. 1, No. 1, www.arabsocialmediareport.com/UserManagement/PDF/ASMR\%20Report\%201.pdf.

Duggan, Maeve (2017): Online Harassment 2017. Pew Research Center, 11 July, www.pewinternet. org/2017/07/11/online-harassment-2017/.

Ember Zoltán (2017): Egyre menôbb a demokrácia a fiatalok körében. 24.hu, március 3., http://24.hu/fn/ gazdasag/2017/03/03/egyre-menobb-a-demokracia-a-fiatalok-koreben/.

Eperjesi Ildikó (2004): Az iszlám és a Nyugat. Hetek, február 6.

Farid, Farid Y. (2015): There are Now 160 Million Internet Users in the Arab World but the Wrong Tweet Could Still Land You in Jail. Quartz, May 11, https://qz.com/402902/there-are-now-160-million-internet-users-in-the-arab-world-but-the-wrong-tweet-could-still-land-you-in-jail-in-many-countries/ .

Fieldhouse, Edward - Tranmer, Mark - Russell, Andrew (2007): Something About Young People or Something About Elections? Electoral Participation of Young People in Europe: Evidence From a Multilevel Analysis of the European Social Survey. European Journal of Political Research, Vol. 46, No. 6, https://doi. org/10.1111/j.1475-6765.2007.00713.x.

Flash Eurobarometer 375 (2013): European Youth: Participation in Democratic Life. TNS Political \& Social, http://ec.europa.eu/commfrontoffice/publicopinion/flash/fl_375_en.pdf.

Ghannam, Jeffrey (2011): Social Media in the Arab World: Leading up to the Uprisings of 2011. Center for International Media Assistance, Washington, D.C.

Gilder, George (1992): Life After Television. W. W. Norton, New York.

Grönlund, Kimmo (2007): Knowing and Not Knowing. The Internet and Political Information. Scandinavian Political Studies, Vol. 30, No. 3, 397-418, https://doi.org/10.1111/j.1467-9477.2007.00186.x.

Gyurkity Péter (2004): Németország: újabb nem a náci weboldalakra. Sg.hu, december 27., www.sg.hu/ cikkek/34970/ nemetorszag_ujabb_nem_a_naci_weboldalakra.

Hofmeister-Tóth Ágnes (2003): Fogyasztói magatartás. Aula Kiadó, Budapest.

Horrigan, John - Lee, Rainie - Fox, Susannah (2001): Online Communities: Networks That Nurture Long-Distance Relationships and Local Ties. Pew Internet \& American Life Project.

Jacques, Martin (2004): Democracy Isn't Working. The Guardian, June 22, www.theguardian.com/politics/2004/jun/22/usa.world.

Kedzie, Christopher R. (1997): Communication and Democracy: Coincident Revolutions and the Emergent Dictators. RAND RGS Dissertation.

Kézdi Beáta (2016): Miért undorodnak a magyar fiatalok a politikától? - tények és kérdések. Kötôszó, április 4., https://kotoszo.blog.hu/2016/04/04/miert_undorodnak_a_magyar_fiatalok_a_politikatol_erdekes_ valaszok_es_tenyek.

Kohlmann, Evan F. (2006): The Real Online Terrorist Threat. Foreign Affairs, September/October, www. foreignaffairs.com/articles/2006-09-01/real-online-terrorist-threat.

Lassányi Tamás (1999): A véleménynyilvánítás szabadsága az Interneten. mek.oszk.hu/01400/01407/01407. htm.

Leonard, Andrew (2004): Trapped in the Echo Chamber. Salon, November 3, www.salon.com/2004/11/03/ echo_chamber_2/.

Lipset, Seymour Martin - Seong, Kyoung-Ryung - Torres, John Charles (1993): A Comparative Analysis of the Social Requisites of Democracy. International Social Science Journal, Vol. 45, No. 2.

Menyhárt Zsolt (2017): Az európai normatív hatalom exportjának kísérlete és kudarcának tényezôi az arab tavasz tükrében. Államtudományi Mühelytanulmányok, 5. évf., 9. sz., 1-13.

Moussa, Mohamed Ben (2016): Evolution Not Revolution: A Longitudinal Study of the Role of the Internet in Morocco's “Third Way”. Journal of Middle East Media, Vol. 12, Spring. 


\section{Polgári Szemle · 14. évfolyam 1-3. szám}

Nagy Niki (2017): Igenis etessük a trollokat! 24.hu, október 8., http://24.hu/tudomany/2017/10/08/ igenis-etessuk-a-trollokat/.

Olson, Mancur (1993): Dictatorship, Democracy, and Development. American Political Science Review, Vol. 87, No. 3, 567-576, https://doi.org/10.2307/2938736.

Oriti, Thomas (2017): Cyberterrorists Targeting Healthcare Systems, Critical Infrastructure. The World Today, October 23, www.abc.net.au/news/2017-10-23/forget-explosives,-terrorists-are-coming-after-cyber-systems $/ 9076786$.

OSCE (2015): Youth Political Participation Must Prevail. Organization for Security and Co-operation in Europe, July 24, www.osce.org/serbia/174441.

Palmer, Angela-Gabrielle (2017): How Vulnerable Are We? The Threat of Cyber-Terrorism. The Governance Post, April 7, www.hertie-school.org/the-governance-post/2017/04/vulnerable-threat-cyber-terrorism/.

Peremiczky Szilvia (2004): Iszlám - A háború és a remény. Hetek, 8. évf., 7. sz.

Pogonyi Szabolcs (2006): Digitális demokrácia vagy kiberbalkán? Világosság, 47. évf., 1. sz., 5-12.

Richey, Sean - Zhu, Junyan (2015): Internet Access Does Not Improve Political Interest, Efficacy, and Knowledge for Late Adopters. Political Communication, Vol. 32, No. 3, 396-413, https://doi.org/10.1080/105 84609.2014.944324.

Robson, Steve (2016): Anti-Terror Police Shutting Down 1,000 ISIS Websites and Social Media Accounts Every Week. Mirror, March 5, www.mirror.co.uk/news/uk-news/anti-terror-police-shutting-down-7503775.

Rowen, Henry S. (1995): The Tide Underneath the „Third Wave”. Journal of Democracy, Vol. 6, No. 1, 52-64, https://doi.org/10.1353/jod.1995.0018.

Ryan, Joseph E. (1993): The Comparative Survey of Freedom, 1992-1993. Survey Methodology. In: McColm, R. Bruce (ed.): Freedom in the World. The Annual Survey of Political Rights and Civil Liberties, $1992-$ 1993. Freedom House, New York.

Sajbl, Clarissa (2012): The Arabic Web: Numbers and Facts. State of Digital, May 14, www.stateofdigital.com/ the-arabic-web/.

Salgado, Susana (2014): The Internet and Democracy Building in Lusophone African Countries. Routledge, New York, USA.

Sartori, Giovanni (1987): The Theory of Democracy Revisited. Chatham House, Chatham.

Shirky, Clay (1995): Voices From the Net. Ziff Davis Press, Emeryville.

Sloam, James (2016): Diversity and Voice: The Political Participation of Young People in the European Union. The British Journal of Politics and International Relations, Vol. 18, No. 3, https://doi. org/10.1177/1369148116647176.

Spears, Russell - Lea, Martin - Stephen, Lee (1990): De-Individuation and Group Polarization in Computer-Mediated Communication. British Journal of Social Psychology, Vol. 29, No. 2, https://doi.org/10.1111/j.2044-8309.1990.tb00893.x.

Stein, Joel (2016): How Trolls Are Ruining the Internet. Time, 18 Aug, http://time.com/4457110/internet-trolls/.

Sunstein, Cass (2001): The daily we. Is the Internet Really a Blessing for Democracy? Boston Review, 1 June, http://bostonreview.net/cass-sunstein-internet-democracy-daily-we.

Sylvester-Bradley, Oliver (2016): Build Democracy and It Spreads Like a Virus. Open Democracy, December 3, www.opendemocracy.net/open2017/oliver-sylvester-bradley/build-democracy-and-it-spreads-like-virusqa-on-platform-co-ops-with-nathan.

Tálas, Péter (2005): A terrorizmus elleni küzdelem néhány dilemmájáról. Hadtudomány, 1. évf., 4. sz.

Teitelbaum, Joshua (2002): Dueling for Da'wa: State vs. Society on the Saudi Internet. Middle East Journal, Vol. 56, No. 2, 222-239.

Touraine, Alain (1992): Mit jelent ma a demokrácia? Magyar Tudomány, 37. évf., 9. sz., 1078-1087.

Wallace, Patricia (2002): Az internet pszichológiája. Osiris Kiadó, Budapest.

Wheeler, Deborah L. (2006): Empowering Publics: Information Technology and Democratization in the Arab World - Lesson From Internet Cafes and Beyond. Oxford Internet Institute Research Report, No. 11, https://doi.org/10.2139/ssrn.1308527. 
Wijesiriwardena, Subha (2017): Is the Internet Really Democratic? How the 'Wired World' Excludes Women and Other Marginalised Persons. World Wide Web Foundation, April 19.

Wucherpfennig, Julian - Deutsch, Franziska (2009): Modernization and Democracy: Theories and Evidence Revisited. Living Reviews in Democracy, September, www.ethz.ch/content/dam/ethz/special-interest/gess/cis/cis-dam/CIS_DAM_2015/WorkingPapers/Living_Reviews_Democracy/Wucherpfennig\%20Deutsch.pdf.

Zakaria, Fareed (1997): The Rise of Illiberal Democracy. Foreign Affairs, November, www.foreignaffairs. com/articles/1997-11-01/rise-illiberal-democracy. 